\title{
PENGEMBANGAN TINDAK BAHASA TERAPI DALAM INTERVENSI ANAK AUTIS SPEKTRUM PERILAKU
}

\author{
Luluk Sri Agus Prasetyoningsih \\ FKIP Universitas Islam Malang \\ email: luluksap58@gmail.com
}

\begin{abstract}
Abstrak
Penelitian ini bertujuan mengembangkan prototipe tindak bahasa terapi dalam intervensi anak autis spektrum perilaku. Penelitian adalah penelitian pengembangan model R2D2 (Recursive, Reflective, Design, and Development). Metode penelitian pengembangan meliputi: desain produk, validasi produk, uji coba, revisi produk, dan membuat produk massal. Pengembangan prototipe tindak bahasa terapi dilakukan secara kolaboratif antara pengembang, tim ahli (ahli bahasa dan ahli klinis) dan praktisi (terapis). Data penelitian diperoleh dari hasil pengamatan (observasi), catatan lapangan, dan kuesioner. Hasil penelitian menunjukkan bahwa pengembangan prototipe tindak bahasa terapi telah memenuhi syarat ketepatan, kegunaan, dan kelayakan. Simpulan hasil penelitian adalah produk prototipe tindak bahasa terapi dalam intervensi anak autis spektrum perilaku telah memenuhi syarat keberterimaan yang dapat digunakan sebagai referensi untuk menangani anak autis gangguan perilaku.
\end{abstract}

Kata kunci: pengembangan, tindak bahasa terapi, intervensi, autis spektrum perilaku

\section{DEVELOPING THERAPEUTIC LANGUAGE ACTS FOR THE INTERVENTION IN CHILDREN WITH BEHAVIORAL SPECTRUM AUTISM}

\begin{abstract}
This study aims to develop a prototype of therapeutic language acts for the intervention in children with behavioral spectrum autism. This was a research and development study employing the R2D2 (Recursive, Reflective, Design, and Development) model. It consisted of product design, product validation, tryout, product revision, and mass production. The prototype of therapeutic language acts was collaboratively developed by involving the developer, expert team (a language expert and a clinical expert), and practitioner (a therapist). The data were collected through observations, field notes, and questionnaires. The results show that the developed prototype of therapeutic language acts satisfies the criteria for accuracy, utility, and appropriateness. The conclusion is that the prototype of therapeutic language acts for the intervention in children with behavioral spectrum autism satisfies the criteria for acceptability and can be used as a reference to deal with children with behavioral disorder autism.
\end{abstract}

Keywords: development, therapeutic language acts, intervention, behavioral spectrum autism

\section{PENDAHULUAN}

Akibat kelainan sistem syaraf pada otak, salah satu ciri yang menonjol pada anak-anak autis adalah munculnya bentuk-bentuk perilaku yang tidak sama dengan aturan sosial. Perilaku ini bisa 
muncul dalam berbagai bentuk, mulai dari yang sederhana seperti tidak bersedia melakukan kontak mata dengan orang lain, tidak merespon, tidak mampu bersosialisasi dan berinteraksi sosial, menyendiri dan pasif (hipoaktif), gerakan-gerakan yang tidak wajar, sampai dengan perilaku-perilaku emosi tidak terkendali seperti agresivitas (hiperaktif), tantrum (mengamuk), perilaku merusak, berteriak-teriak, menjerit, berbicara sendiri, dan perilaku tidak wajar lainnya. Berdasarkan laporan dalam International Journal of Special Education (Laughlin, 2002) menyatakan bahwa anak autis merupakan anak dengan kelainan khusus yang berkaitan dengan perilaku yang kompleks dan meluas.

Anak autis gangguan perilaku perlu mendapatkan intervensi atau terapi dalam rangka membangun kondisi yang lebih baik. Melalui terapi secara rutin, munculnya kelainan-kelainan pada anak autis secara bertahap dapat diatasi. Terapi perilaku merupakan tindakan atau pembelajaran untuk membantu menangani gangguan perilaku yang dialami oleh anak. Apabila terapi dilakukan sejak dini dan konsisten maka dapat membantu mengurangi gejala-gejala autis.

Terapi perilaku bagi anak autis dimaksudkan mengurangi masalah penyimpangan perilaku, baik defisit (hipoaktif) maupun eksesif (hiperaktif). Setiap anak autis memerlukan penanganan dan tergantung pada jenis dan tingkat gangguan yang dialami oleh anak. Varian tingkat gangguan perilaku setiap anak juga berbeda-beda. Ada varian tingkat ringan dan ada juga yang berat. Masing-masing varian gangguan perilaku memerlukan terapi sesuai dengan karakteristik kondisi individual anak (Wijayakusuma, 2008:v).

Terapi perilaku merupakan teknik terapi dalam bentuk pelatihan dan pembelajaran yang bertujuan untuk membangun perilaku-perilaku baru yang secara sosial bermanfaat. Terapi perilaku dimaksud- kan untuk menumbuhkan perilaku baru seperti komunikasi secara spontan dan kemampuan melakukan interaksi sosial dengan orang lain. Melalui terapi ini anakanak autis diajak untuk belajar dari situasi wajar di sekitar mereka agar anak dapat membedakan berbagai macam rangsangan yang diterima dan meresponnya dengan cara yang benar (Sunu, 2012:41).

Program-program untuk penanganan perubahan perilaku yang menyimpang meliputi: pengajaran keterampilan sosial yang bertarget, atau bantuan agar anak dapat menggeneralisasikan sesuatu, dan mencakup alternatif-alternatif perilaku yang spesifik. Agar efektif dalam menangani anak autis, munculnya penyimpangan perilaku perlu dicatat dan selanjutnya dijadikan pertimbangan penanganan dan evaluasi.

Pada umumnya terapi untuk menangani gangguan perilaku anak autis dilakukan dengan menggunakan model Applied Behaviour Analysis (ABA). Model ini dapat membimbing anak autis gangguan perilaku agar patuh (bukan takut) dan kreatif. Ada beberapa prinsip terapi perilaku model $A B A$. Penatalaksananan terapi dilakukan secara terstruktur. Terapis menggunakan teknik terapi secara terprogram dengan jelas. Dalam kegiatan intervensi pelaksananan program terarah. Panduan program yang dibuat oleh terapis digunakan sebagai acuan terapi. Penatalaksanaan terapi dilakukan secara terukur, dapat diketahui keberhasilan atau kegagalan dengan pasti. Tingkat pecapaian program terapi dapat diukur berdasarkan kriteria yang disusun oleh terapis (Marjuki, 2015:4 - 5).

Hasil penelitian pendahuluan menunjukkan bahwa dengan terapi model $A B A$, terapis dalam mengintervensi anak autis menggunakan tindak komunikasi klinis. Pada kegiatan terapi perilaku, terapis berusaha memberikan stimulus agar klien autis dapat memberikan respon perilaku dengan benar. Respon-respon perilaku 
dan tindak bahasa yang diberikan oleh anak merupakan data yang penting bagi terapis. Setiap respon perilaku dan tindak bahasa anak autis perlu dihargai dan menjadi pijakan oleh terapis untuk menentukan program terapi. Hal ini sesuai dengan hasil penelitian Prasetyoningsih (2014:264) tentang tindak bahasa terapi dalam intervensi anak autis. Hasil studi pendahuluan menunjukkan bahwa dalam intevensi anak autis, terapis menggunakan tindak bahasa. Temuan penting dalam studi pendahuluan ini juga menunjukkan bahwa dalam intervensi anak autis, terapis mengalami hambatan untuk mendapatkan buku-buku rujukan tindak bahasa terapi (verbal dan nonverbal).

Pada umumnya buku-buku rujukan yang sudah diterbitkan hanya mengkaji tindak bahasa bagi penutur normal. Searle (1983:54 - 64) dan Rahardi (2002:35 - 36) dalam bukunya membagi tindak bahasa menjadi tiga jenis, yaitu tindak lokusi, perlokusi, dan ilokusi. Selanjutnya, Levinson (1985:240) membagi tindak tutur ilokusi menjadi lima jenis, yaitu (1) tindak asertif, (2) tindak direktif, (3) tindak komisif, (4) tindak ekspresif, dan (5) tindak deklarasi. Dalam pembahasan tindak tutur tersebut, tidak ada penjelasan bagaimana jenis tindak tutur bagi penutur yang mengalami gangguan akibat kelainan sistem syaraf pada otak, seperti pada kasus autis.

Fakta di lapangan menunjukkan bahwa saat ini belum ada buku tindak bahasa terapi yang dapat digunakan oleh terapis sebagai referensi dalam intervensi anak autis gangguan perilaku. Pada umumnya terapis menggunakan buku-buku tentang autis yang bersifat umum dan belum memberikan acuan komunikasi klinis dalam intervensi autis gangguan perilaku. Buku-buku dan artikel hasil penelitian tentang autis yang sudah diterbitkan pada umumnya berisi pengetahuan hal ikhwal autis, misalnya Autisme pada Anak (Handoyo, 2009), Amazing Autisme
(Priyatna, 2010), Penguasaan Bahasa pada Anak Autis (Prasetyoningsih, 2007), dan Program Terapi Anak Autis di SLB Negeri Semarang (Bektiningsih, K., 2009).

Hasil penelusuran di lapangan menunjukkan bahwa dalam hal intervensi anak autis gangguan perilaku, para terapis belum menggunakan buku rujukan khusus tindak komunikasi klinis. Hal ini, disebabkan belum ada buku referensi tentang tindak bahasa terapi. Oleh karena itu, kehadiran buku tindak bahasa terapi ini penting bagi terapis, ahli klinis, orang tua, atau keluarga yang memiliki anak autis spektrum perilaku.

Berdasarkan pertimbangan tersebut perlu dikembangkan buku tindak bahasa terapi dalam intervensi klinis anak autis spektrum perilaku. Melalui pengembangan prototip tindak bahasa terapi berbasis pragmatik klinis (Cumming, 2009) ini diharapkan dapat membantu terapis dan masyarakat dalam menangani anak autis gangguan perilaku.

Berdasarkan latar belakang tersebut perlu ada penelitian pengembangan produk tindak bahasa terapi untuk menangani anak autis. Penelitian ini bertujuan mengembangkan prototip tindak bahasa terapi yang memenuhi syarat ketepatan (accuracy), kegunaan (utility), dan kelayakan (feasibility) yang dapat dijadikan rujukan intervensi anak autis spektrum perilaku. Penelitian pengembangan prototip tindak bahasa terapi dalam intervensi anak autis gangguan perilaku ini termasuk penelitian rintisan.

Fakta empiris menunjukkan bahwa saat ini belum ada buku yang mengkaji tindak bahasa terapi, baik verbal maupun nonverbal. Berdasarkan hal tersebut peneliti termotivasi untuk mengembangkan prototip tindak bahasa terapi untuk anak autis, dengan harapan hasil pengembangan produk ini dapat memberikan kontribusi untuk penanganan anak autis gangguan perilaku. 


\section{METODE}

Penelitian rintisan ini bertujuan mengembangkan prototip tindak bahasa terapi yang dapat diterima (acceptability) dan digunakan sebagai referensi dalam intervensi klinis anak autis gangguan perilaku. Untuk mencapai target yang diharapkan, peneliti menggunakan jenis penelitian pengembangan.

Penelitian pengembangan ini didasarkan atas hasil penelitian kualitatif (tahun pertama) tentang pola-pola tindak komunikasi klinis dalam intervensi anak autis gangguan perilaku. Berdasarkan temuan penelitian tersebut, selanjutnya peneliti mengembangkan prototip tindak bahasa terapi dalam intervensi anak autis, dengan harapan hasil penelitian berupa produk buku ini dapat digunakan oleh terapis sebagai rujukan dalam menangani anak autis spektrum perilaku.

Penelitian pengembangan ini menggunakan model R2D2 (Recursive, Reflective, Design, and Development) yang dirancang oleh Willis (1995 dan 2000). Model pengembangan ini mencakup empat prinsip. (1) Dalam prinsip recursive, mengizinkan pengembang menetapkan keputusan sementara dan meninjau kembali keputusannya tentang produk atau proses pengembangan, termasuk perbaikan yang diperlukan. (2) Prinsip reflective, menuntut pengembang untuk merefleksi, memikir ulang, mencari dan menemukan masukan (umpan balik) dari berbagai sumber selama proses perancangan dan pengembangan produk. (3) Prinsip design, mengizinkan pengembang memulai pengembangan produk secara fleksibel berdasarkan kondisi lapangan. (4) Prinsip development, pengembang melibatkan tim pengembang secara kolaboratif antara pengembang, tim ahli (ahli bahasa dan ahli klinis) dan praktisi (terapis).

Alur pengembangan prototip produk ini ada empat langkah, yaitu pendefinisian (persiapan dan pembetukan tim pengembang), perancangan produk pengemba- ngan (difokuskan pada kegiatan analisis karakteristik subjek penelitian dan klien), pengembangan penulisan draf produk, uji coba hasil produk, dan penyebarluasan produk tindak bahasa terapi untuk menangani anak autis gangguan perilaku. Pengembangan prototip tindak bahasa terapi dilakukan secara kolaboratif antara pengembang, tim ahli, dan praktisi.

Instrumen dan pengambilan data penelitian dilakukan menggunakan kuesioner atau angket untuk uji lapangan (praktisi) dan uji ahli, pengamatan atau observasi, serta catatan lapangan dilakukan terhadap subjek penelitian (uji kelompok kecil). Data penelitian dianalisis dengan menggunakan teknik analisis kualitatif dan kuantitatif (statistik deskriptif).

Data kualitatif diperoleh dari hasil pengamatan (observasi) pada saat uji ahli dan uji lapangan. Data ini diperoleh melalui respon dan catatan lapangan dalam instrumen penelitian. Data kuantitatif diperoleh melalui hasil uji produk. Uji coba produk dilakukan pada subjek penelitian (kelompok kecil) praktisi atau terapis yang menangani anak autis spektrum perilaku (defisit dan eksesif). Uji ahli dilakukan oleh ahli (ahli bahasa dan ahli klinis). Uji coba prototip diarahkan pada pengembangan terhadap tiga aspek, yaitu sistematika dan tampilan, pengembangan isi (materi), serta aspek kebahasaan.

Aspek susunan atau sistematika prototip tindak bahasa terapi dalam intervensi anak autis spektrum perilaku terdiri atas delapan Bab. Setiap Bab dalam prototip diawali dengan pengantar kemudian diikuti substansi materi. Sistematika atau susunan prototip sebagai berikut: Halaman Judul, Halaman Sampul Dalam, Kata Pengantar, Daftar Isi, Isi Buku, Daftar Pustaka, dan Biografi Penulis. Aspek tampilan atau perwajahan prototip mencakup penggunanan huruf dan ilustrasi atau gambar. Tampilan gambar berhubungan dengan contoh kegiatan intervensi anak autis gangguan perilaku. 
Aspek isi atau substansi materi prototip tindak bahasa terapi dalam intervensi anak autis spektrum perilaku terdiri atas sembilan materi (hakikat autis, autis gangguan perilaku, terapi perilaku, jenis tindak komunikasi, fungsi tindak komunikasi, strategi tindak komunikasi, tindak komunikasi klinis dalam terapi perilaku, fungsi tindak komunikasi dalam terapi perilaku, strategi tindak komunikasi dalam terapi perilaku, dan lampiran).

Aspek kebahasaan dan keterbacaan prototip tindak bahasa terapi dalam intervensi anak autis spektrum perilaku yang dikembangkan meliputi: pemilihan huruf, sistem penulisan, keterbacaan (struktur kata dan penyusunan kalimat), dan penulisan paragraf.

\section{HASIL DAN PEMBAHASAN}

Penelitian ini menghasilkan prototip tindak bahasa terapi dalam intervensi klinis anak autis spektrum perilaku, baik defisit (hipoaktif) maupun eksesif (hiperaktif). Hasil pengembangan prototip ini difokuskan pada tiga aspek, yaitu (a) pengembangan susunan atau sistematika prototip, (2) pengembangan isi atau substansi materi, dan (3) aspek kebahasaan prototip tindak bahasa terapi. Selanjutnya, pembahasan hasil penelitian pengembangan dikaitkan dengan kajian teori dan fakta empiris tentang referensi tindak bahasa terapi dalam intervensi anak autis spektrum perilaku.

\section{Pengembangan Aspek Susunan atau Sistematika}

Hasil pengembangan aspek susunan atau sistematika dan tampilan prototip tindak bahasa terapi menunjukkan adanya ketepatan dalam penyusunan atau penataan (urutan) materi yang meliputi bagian pengantar (ilustrasi, sampul luar, sampul dalam, kata pengantar, dan daftar isi), bagian isi (dimulai dari wawasan atau teori tentang autis dan selanjutnya diikuti materi pokok tindak bahasa terapi), dan pada bagian akhir berisi daftar rujukan dan biografi penulis. Hasil analisis data menunjukkan bahwa hasil pengembangan aspek susunan atau sistematika prototip memperoleh skor 3,4 (rentang skor $1-4)$.

Hasil pengembangan aspek susunan atau sistematika prototip tindak bahasa terapi terdapat catatan revisi, antara lain perlu diberikan ilustrasi gambar pada sampul luar (cover) dan sampul dalam tentang gambar pola intervensi klinis anak autis spektrum perilaku. Hal ini dimaksudkan agar produk buku referensi lebih menarik dan memberikan gambaran tentang tindak bahasa terapi dalam intervensi klinis anak autis gangguan perilaku. Hasil penelitian ini sesuai dengan temuan penting dalam studi pendahuluan Prasetyoningsih (2014) bahwa dalam intervensi klinis para terapis mengalami hambatan untuk mendapatkan buku-buku rujukan tentang tindak bahasa terapi.

\section{Pengembangan Isi atau Materi}

Isi atau materi tindak bahasa terapi yang dikembangkan meliputi kajian teoretis dan pragmatis (penerapan) tindak bahasa terapis dalam intervensi klinis. Prototip buku ini berorientasi pada pragmatik klinis, yaitu penggunanan bahasa untuk tujuan komunikasi klinis. Materi prototip tindak bahasa terapi meliputi: hakikat autis, gangguan perilaku, terapi perilaku, kajian teoretis tindak komunikasi, jenis tindak komunikasi klinis untuk terapi perilaku, fungsi tindak komunikasi klinis untuk terapi perilaku, dan strategi tindak komunikasi klinis untuk terapi perilaku, dan hasil kajian tindak bahasa terapi dalam intervensi autis spektrum perilaku dengan gangguan pragmatik. Hasil pengembangan berdasarkan aspek isi atau materi tentang prototip tindak bahasa terapi menunjukkan adanya ketepatan, kegunaan, dan kelayakan isi atau materi tindak bahasa terapi sebagai referensi dalam intervensi klinis anak 
autis gangguan perilaku. Hasil analisis data yang terkait pengembangan isi atau materi prototip menunjukkan perolehan skor 3,6 (rentang skor $1-4$ ).

Dalam pengembangan ini terdapat tiga catatan penting (revisi) penyempurnaan isi atau materi prototip tindak bahasa terapi. Pertama, dalam produk prototip tindak bahasa perlu ditambahkan contoh konkret kegiatan intervensi anak autis spektrum perilaku. Kedua, pada bagian isi atau materi diperlukan penambahan lampiran program terapi perilaku sebagai acuan terapi berdasarkan tingkatan penanganan anak autis. Ketiga, terdapat catatan yang secara umum menunjukkan bahwa kehadiran prototip buku tindak bahasa terapi ini bermanfaat karena dapat digunakan sebagai rujukan oleh terapis dalam intervensi anak autis gangguan perilaku.

Hasil penelitian ini sesuai dengan fakta di lapangan bahwa saat ini belum ada buku tindak bahasa terapi yang dapat digunakan oleh terapis sebagai referensi dalam intervensi anak autis gangguan perilaku. Buku-buku dan artikel hasil penelitian tentang autis yang sudah diterbitkan pada umumnya berisi tentang keautisan, misalnya Autisme pada Anak (Handoyo, 2009) dan Program Terapi Anak Autis di SLB Negeri Semarang (Bektiningsih, K., 2009).

\section{Pengembangan Aspek Kebahasaan}

Hasil pengembangan berdasarkan aspek kebahasaan dalam prototip menunjukkan adanya ketepatan dan kemudahan keterbacaan prototip (penggunaan kata dan struktur kalimat). Hasil analisis data pengembangan aspek kebahasaan menunjukkan perolehan skor 3,2 (rentang skor $1-4)$.

Hasil pengembangan aspek kebahasaan terdapat catatan revisi tentang penggunaan istilah. Dalam prototip tindak bahasa terapi, penggunaan istilah teknis perlu disertai penjelasan atau keterangan.
Secara ringkas hasil penelitian pengembangan ketiga aspek ini menunjukkan bahwa prototip tindak bahasa terapi dapat diterima dan digunakan sebagai referensi dalam intervensi klinis anak autis gangguan perilaku, baik defisit maupun eksesif. Perolehan skor rata-rata tentang keberterimaan produk tindak bahasa terapi sebesar 3,4 (kriteria perolehan skor 3-4 adalah memenuhi syarat keberterimaan). Artinya, perolehan skor menunjukkan bahwa produk buku tindak bahasa terapi dapat digunakan sebagai rujukan dalam intervensi anak autis gangguan perilaku.

Secara umum, hasil penelitian ini dapat melengkapi pendapat Sunu (2012:3) bahwa seiring dengan semakin bertambah jumlah anak-anak yang mengalami gejala autis, maka kebutuhan tentang wawasan keautisan dan cara penanganannya juga semakin meningkat. Oleh karena itu, penting memberikan wawasan tentang autis dari berbagai perspektif dan spektrumnya melalui pengembangan produk buku tindak bahasa terapi yang dapat digunakan oleh terapis untuk menangani anak autis gangguan perilaku.

Kecenderungan di lapangan juga menunjukkan bahwa pada umumnya masyarakat belum memiliki pemahaman yang benar tentang autis. Khususnya dalam memberikan layanan pada pendidikan khusus sehingga belum sesuai dengan harapan (Delphie, 2009:ix). Hal ini, disebabkan terbatasnya produk atau buku-buku yang berkaitan dengan penanganan perkembangan anak, khususnya anak yang berada di luar kewajaran, baik dari segi perilaku maupun perkembangan sensorinya.

Hasil pengembangan prototip tindak bahasa terapi ini dapat melengkapi teori tindak tutur atau tindak bahasa (Searle, 1983) dan kajian pragmatik klinis. Teori tindak bahasa Searle hanya berhubungan dengan tindak tutur pada manusia normal. Hasil penelitian pengembangan 
ini berkenaan dengan tindak bahasa pada anak yang mengalami kelainan sistem syaraf pada otak sehingga menyebabkan gangguan perilaku. Buku yang berjudul Pragmatik Klinis yang ditulis oleh Cumming (2009) juga belum menjelaskan secara rinci bagaimana tindak bahasa terapi, baik verbal maupun nonverbal. Oleh karena itu, kehadiran prototip tindak bahasa ini dapat melengkapi kajian pragmatik klinis.

\section{SIMPULAN}

Penelitian ini bertujuan mengembangkan prototip tindak bahasa terapi dalam intervensi anak autis spektrum perilaku (defisit dan eksesif). Hasil penelitian menunjukkan bahwa pengembangan prototip produk telah memenuhi syarat kegunaan, ketepatan, dan kelayakan. Pengembangan kegunaan berhubungan dengan kemanfaatan prototip tindak bahasa terapi sebagai buku referensi yang dapat dijadikan rujukan dalam menangani anak autis spektrum perilaku. Pengembangan ketepatan berkaitan dengan aspek susunan atau sistematika prototip tindak bahasa terapi dalam intervensi anak autis spektrum perilaku. Pengembangan kelayakan berkenaan dengan aspek kesesuaian dengan kebutuhan wawasan atau pengetahuan tentang tindak komunikasi berbasis pragmatik klinis.

Simpulan hasil penelitian adalah produk prototip tindak bahasa terapi dalam intervensi anak autis spektrum perilaku yang dikembangkan telah memenuhi syarat keberterimaan (acceptability) sebagai buku referensi. Temuan penelitian ini berimplikasi bahwa kehadiran buku tindak bahasa terapi bermanfaat dan dapat digunakan untuk membantu menangani anak autis gangguan perilaku, baik defisit maupun eksesif.

Berdasarkan hasil penelitian ini penting diberikan saran kepada pihak terkait penanganan Anak Berkebutuhan Khusus (ABK) autis spektrum perilaku. Disaran- kan kepada pihak profesional (ahli klinis dan terapis), orang tua, atau keluarga yang menangani anak autis gangguan perilaku agar menggunakan referensi tindak bahasa terapi dalam intervensi klinis anak autis. Kesalahan penggunakan tindak bahasa terapi dapat menyebabkan anak tidak memahami maksud komunikasi dan bahkan bisa membuat anak frustrasi dan berdampak pada perilaku negatif. Oleh karena itu, disarankan agar tidak sembarang berbicara dengan anak autis. Terapis dan orang tua atau keluarga disarankan memperbanyak wawasan tentang keautisan serta penanganannya.

\section{UCAPAN TERIMA KASIH}

Penelitian ini disusun berdasarkan hasil penelitian fundamental tahun kedua yang dilaksanakan pada tahun 2015 dengan dukungan anggaran DIPA dalam rangka penelitian Desentralisasi Tahun Anggaran 2015, Nomor SP-DIPA: 018 SP2H/P/K7/KM/2015, Tanggal, 2 April 2015. Ucapan terima kasih disampaikan kepada Rektor Universitas Islam Malang (Unisma), Lembaga Penelitian dan Pengabdian Kepada Masyarakat Unisma, dan semua staf administrasi yang telah memfasilitasi hingga penelitian fundamental ini dapat diselesaikan dengan baik. Semoga penelitian ini bermanfaat bagi kalangan akademisi, pemerhati ABK, profesional yang menangani ABK Autis (ahli klinis, psikolog, dan terapis), dan orang tua atau keluarga yang memiliki anak autis spektrum perilaku.

\section{DAFTAR PUSTAKA}

Bektiningsih, K. 2009. Program Terapi Anak Autis di SLB Negeri Semarang. Jurnal Kependidikan. 39. (2): 85-110.

Cummings, Louise, 2009. Clinical Pragmatics. Cambridge: Cambridge University Press.

Delphie, Bandi. 2009. Pendidikan Anak Autis. Klaten: PT Intan Sejati. 
Handojo, Y. 2009. Autisme: Menyiapkan Anak Autis untuk Mandiri dan Masuk Sekolah Reguler dengan Metode ABA Basic. Jakarta: PT Bhuana Ilmu Populer. Kelompok Gramedia.

Levinson, S.C. 1985. Pragmatics. Cambridge: Cambridge University Press.

Laughlin, T.F. 2002. Autism: Characteristics, Causes, and Some Educational Interventions. International Journal of Special Education. Vol. 17 (2). 1-10.

Marjuki, 2015a. AUTISM. Materi Pelatihan Disampaikan di College of Allied Educators. Surabaya: CAE Surabaya dalam Short Course-Special Needs Education, 14 Februari 2015.

Marjuki, 2015b. Applied Behaviour Analysis $(A B A)$. Materi Pelatihan Disampaikan pada Seminar dan Workshop di Fathers Heart. Surabaya: Learning Center for Children with Special Needs.

Prasetyoningsih, Luluk Sri Agus. 2007. Penguasaan Bahasa pada Anak Autis dan Pemanfaatan Media Pembelajarannya. Jurnal Wahana Sekolah Dasar, 15 (2):145 - 155.

Prasetyoningsih, Luluk Sri Agus. 2014. Tindak Bahasa Terapis dalam Intervensi Klinis pada Anak Autis. Jurnal
LITERA. Jurnal Penelitian bahasa, sastra, dan Pengajarannya. Volume 13 (2):264 $-276$.

Priyatna, A. 2010. Amazing Autizm, Memahami, Mengasuh, dan Mendidik Anak Autis. Jakarta: PT Gramedia.

Rahardi, K. 2002. Pragmatik: Kesantunan Imperatif Bahasa Indonesia. Jakarta: Penerbit Erlangga.

Searle, John R. 1983. Speech Acts. An Essay in the Philosophy of Language. London: Cambridge University Press.

Sunu, C. 2012. Unlocking Autsm. Yogyakarta: Lintang Terbit.

Wijayakusuma, Hembing. 2008. Psikoterapi Anak Autisma. Teknik Bermain Kreatif Nonverbal dan Verbal. Terapi Khusus Untuk Autisma. Jakarta: Pustaka Populer Obor.

Willis, J. 1995. A Recursive, Reflective Instructional Design Model Based on Constructivist Interpretivist Theory. Educational Technology/Nov-Dec, 9.

Willis, J. 2000. A General Set of Procedures for Constructivist Interpretivist Instructional Design: the New R2D2 Model. Educational Technology/March-April, 2. 